\title{
Polymerase Chain Reaction (PCR) and How Temperature Modifies Nucleotide Pairings
}

\author{
Alicia García Falgueras* \\ University Researcher, Netherlands Institute for Neuroscience, Spain \\ Submission: December 25, 2020; Published: January 27, 2021 \\ *Corresponding author: Alicia García Falgueras, University Researcher, Netherlands Institute for Neuroscience, Spain
}

\begin{abstract}
Polymerase Chain Reaction (PCR) is a molecular technique more suitable for accurate diagnoses because of its specificity in targeting and identifying specific pathogens. PCR technique is reliable to detect the genetic presence of the virus in the host since the very beginning of the infection, no matter how the immune system of the person might react. Moreover, the samples for the test contains the DNA information during quite a long time since the extraction. Programmable thermal operation cycler for controlling heating and cooling is the procedure to denaturation into two single strands, annealing and extension reactions of the DNA. The PCR is certainly having a clinical approach, because do not emphasized on how the immune system of the patient might reacts to the infection, only on whether the specific virus is present or not for the accurate diagnoses and subsequently proceed with an appropriated medical treatment to restore health.
\end{abstract}

Keywords: Polymerase chain reaction; Immune system; Thermal operation cycler; Nucleotide pairings

\section{Introduction}

\section{Theoretical principles of the PCR}

To identify genotypes characteristics for basic and ethical clinical research the PCR has been of extended use [1-3] and remains by far the most widely used. Differences in genotypes of certain population with a) a mutation can be detected with PCR [1] or b) to described and define a specific population depending on their hetero or homozygosis for certain genes, the PCR procedure is applied [2,3]. Genome of most of species have been publicly disclosed and genome sequencing can be used by researchers to design primers for PCR for their experiments to probe fragments bases pair (bp) as simple primer sequences (5'-3'), length polymorphisms (SSPLs, microsatellites), etc. [2,3]. PCR primers are between 18 and 30 nucleotides in length and should preferably include a guanine + cytosine pair (GC). The Thermus acuaticus (Taq DNA polymerase, originally isolated by Chien et al., 1976 [4]), Pyroccocus furiosus (Pfu DNA polymerase), Thermus thermophilus (Tth polymerase, for RNA templates) and Thermococcus litoralis (VentTM DNA polymerase) are the most commonly enzymes, thermophilic microorganisms, used to copy the DNA: they are high heat resistant $\left(95^{\circ} \mathrm{C}\right)$ and able to synthesize nucleotides which are the four basic bases-molecules essential for life $(A, T, C, G)$ and are amplified each successive cycle doubles the amount of DNA product [5]. Since its original description in 1985 by Kary Mullis [6], the PCR technique has evolved into a multitude of varied methodologies. Because of the natural components of the PCR, this technique has shown a surprising robustness: 1) the impressive ability of almost all oligodeoxynucleotides to bind tightly and discriminating to their specific complementary nucleic acid sequences, 2) the fact each component is necessary and sufficient for the reaction, acting each one in the same probability in a cascade and 3) the evidence that the mechanism is related to the branching structure of its robust propagation and amplification [6].

The abundant and exponential amplification of a very small amount of template DNA are the constant theoretical and technical aspects of the PCR, to analyze followed by specific enzymatic restriction digestions (i. e. Sau96I; Hhal) according to the nucleotide sequence which needs to be localized. Whole samples of blood are lysis buffered to open the cells, filtered, rinsed, washed several times, till DNA elution to be amplified is isolated via centrifuged by spinning the different solutions through the deposit assembly. This sedimentation according to their molecular weight is the reason why they are easily distinguished on the three dimensional matrix of agarose gel electrophoresis. Due to their different biomolecular sizes they are vertically possible to see and distinguish under UV light $[3,7,8]$. Programmable thermal operation cycler for controlling heating and cooling is the procedure to denaturation to two single strands, annealing and extension reactions of the DNA (Figure 1). The following protocol 
conditions is commonly used: $95^{\circ} \mathrm{C}, 50$ seg., $57^{\circ} \mathrm{C} 50$ seg., $72{ }^{\circ} \mathrm{C}$, $50 \mathrm{seg}$., (from 25-40 cycles, total 2 hours) with a final extension at $72{ }^{\circ} \mathrm{C}$ for $10 \mathrm{~min}$. [3,7], but temperatures can be slightly modified for optimizing assay conditions, as well as reagent conditions and incubation times. The annealing temperatures varies from $57^{\circ} \mathrm{C}$ to $64^{\circ} \mathrm{C}$ [3]. This is how sensitivity to increases and decreases of temperature is such a delicate issue for the efficiency and efficacy of this technique. Sensitivity of PCR technique for coronavirus diagnosis in contexts of a high prevalence is $86 \%$, having a specificity of $96 \%$ [9].

\section{Polymerase chain reaction - PCR}

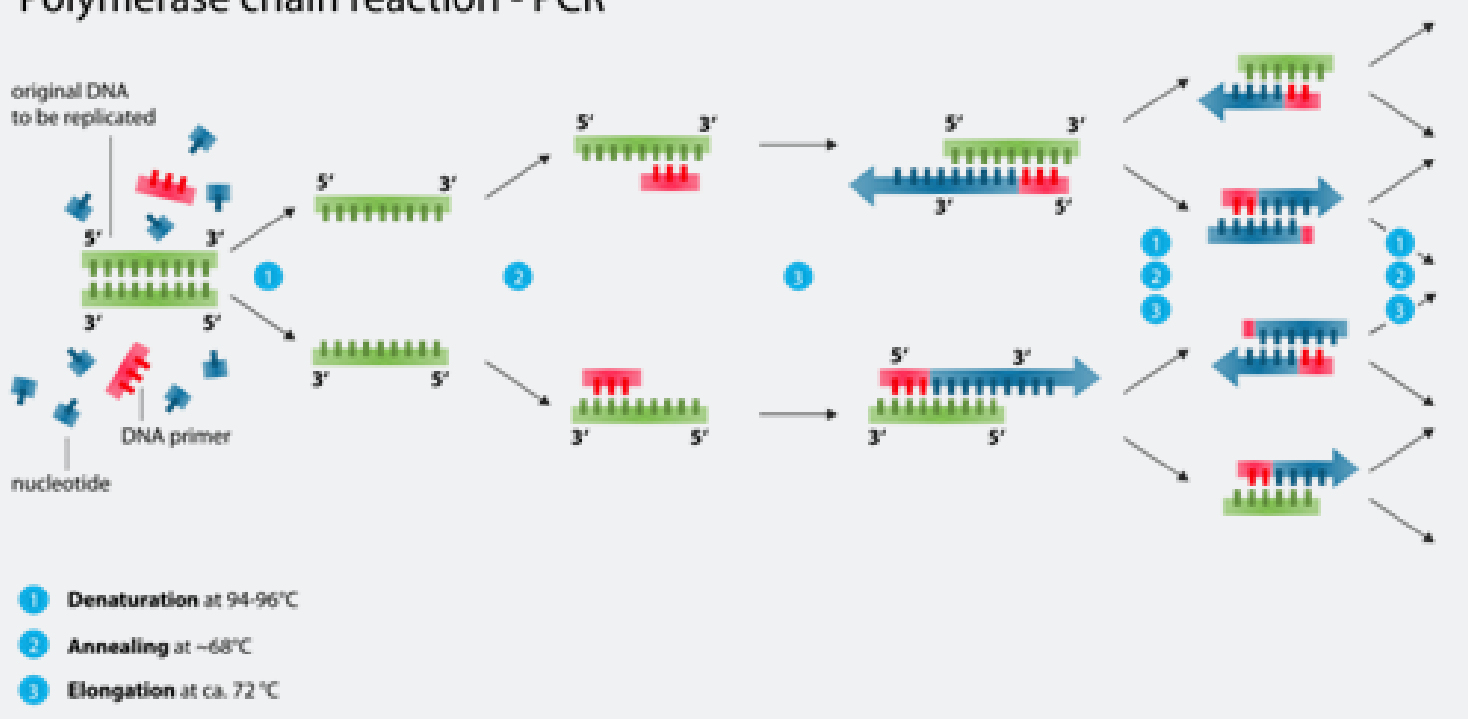

Figure 1: Schematic representation of different steps in PCR procedure where the DNA strands are separated (denaturation), then the specific segment selected (primers) are rewritten with new and equivalent nucleotides (annealing) and this process is repeated exponentially (elongation).

\section{Clinical Application of PCR for Diagnosing Covid-19}

PCR as a molecular technique is more suitable for accurate diagnoses because of its specificity in targeting and identifying specific pathogens [10]. Testing nucleotic acids amplification (NAAT) is the primary method of COVID-19 diagnoses and it has been recommended by the WHO for the better patients tests [11]. Samples are not only whole blood as described, but also respiratory samples (nasal and throat swabs), reliable 8 days after symptom onset. SARS-CoV-2 virus has four structural proteins which can be identify with optimized PCR and RT-PCR protocols. The coronaviruses have a genome size of about 30 kilobases (kb) [11]. Several kits have been approved for detecting SARSCoV-2 however, the reverse transcriptase PCR (RT-PCT) and the Real-Time Reverse transcriptase PCR (rRT-PCR) with respiratory samples are the most commonly method used for diagnoses to detect the virus genetically (Figure 2). Due to the rapid spread of coronavirus diseases a reliable detectable method is needed for an accurate diagnose [11]. The sequenced RNA of the virus which belongs to specific synthesis of proteins, is transcript into complementary DNA (cDNA) strands and subsequently the selected fragments of cDNA is amplified [9]. After increasing the number of DNA molecules, detection and visualization of nucleotides combinations are usually done by methods like agarose gel electrophoresis [11].

\section{Conclusion}

PCR technique is reliable to detect the genetic presence of the virus in the host since the very beginning of the infection and first symptoms appear, no matter how the immune system of the person might react. Moreover, the samples for the test contains the virus DNA information during quite a long time since the extraction (8 days at least). This technique is delicate and requires specific protocols and temperatures to success in the location but errors are minimum due to the exponential amplification of the DNA sequences. The PCR is certainly having an ethical clinical approach diagnosis in contexts of a high prevalence of infections. That is due because PCR does not emphasized on how the immune system of the patient might reacts to the virus, but only on whether the specific virus is genetically present or not for the accurate diagnoses. Subsequently after virus detection genetically it is possible to proceed with an appropriated medical treatment to restore health on affected patients.

\section{Acknowledgement}

We would like to thank the Netherlands Institute for Neuroscience in Amsterdam for their kind deference allowing the NIN affiliation in this review. 

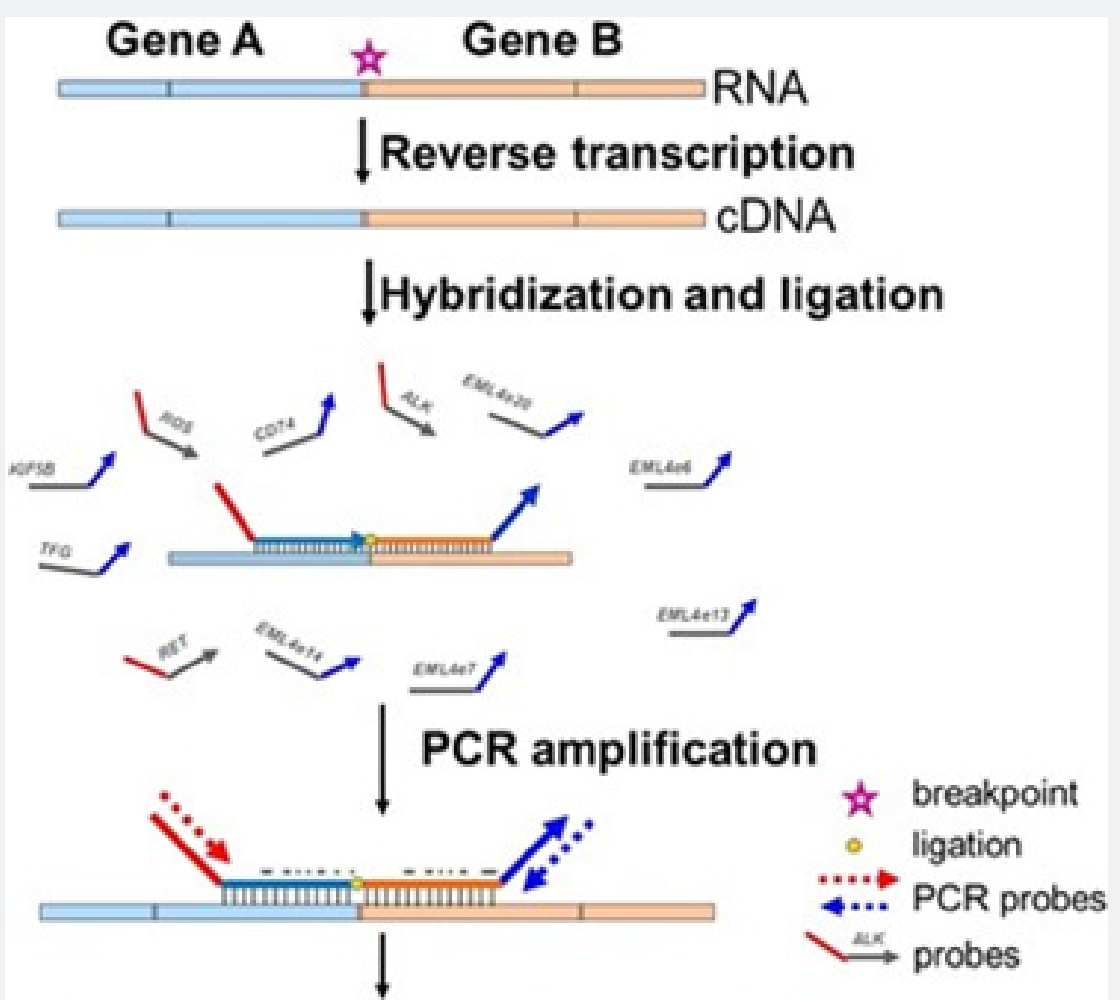

\section{Pyrosequencing or NGS analysis}

Figure 2: Schematic representation of the RT-PCR, the most common technique used for COVID-19 diagnoses. Notice the initial step is done over RNA of known amino acids for virus proteins to obtain complementary DNA (mirror version) which is amplified similarly as standard quantitative PCR but with the perspective of a mirror in its nucleotide sequence.

\section{Competing Interests}

Author has declared that no competing interests exist.

\section{References}

1. Garcia FA, Pinos H, Collado P, Pasaro E, Jordan L, et al. (2005) The role of the androgen receptor in CNS masculinization. Brain Res 1035(1): 13-23.

2. Garcia FA, Pinos H, Collado P, Pasaro E, Guillamon A, et al. (2005) The expression of brain sexual dimorphism in artificial selection of rat strains. Brain Res 1052(2): 130-138.

3. Garcia FA, Pinos H, Fernández R, Collado P, Pasaro E, et al. (2006) Sexual dimorphism in hybrids rats. Brain Res 1123(1): 42-50.

4. Chien A, Edgar DB, Trela JM (1976) Deoxyribonucleic acid polymerase from the extreme thermophile Thermus aquaticus. J Bacteriol 127(3): $1550-1557$

5. Wages JM Jr, Cai D, Fowler AK (1994) Removal of contaminating DNA from PCR reagents by ultrafiltration. Biotechniques 16(6): 1014-1017.
6. Mullis KB (1990) Target amplification for DNA analysis by the polymerase chain reaction. Ann Biol Clin (Paris) 48(8): 579-582.

7. Guo C, Marynen P, Cassiman JJ (1993) A rapid, semiautomated method for apolipoprotein E genotyping. PCR Methods Appl 2: 348-350.

8. Fernandez R, Collado P, Garcia DS, Garcia FA, Guillamon A, et al. (2003) A molecular method for classifying the genotypes obtained in a breeding colony from testicular feminized (Tfm) rats. Horm Metab Res 35(3):1 97-200.

9. Floriano I, Silvinato A, Bernardo WM, Reis JC, Soledade G (2020) Accuracy of the Polymerase Chain Reaction (PCR) test in the diagnosis of acute respiratory syndrome due to coronavirus: a systematic review and meta-analysis. Rev Assoc Med Bras (1992) 66(7): 880-888.

10. Udugama B, Kadhiresan P, Kozlowski HN, Ayden M, Vanessa YC, et al (2020) Diagnosing COVID-19: The Disease and Tools for Detection. ACS Nano 14(4): 3822-3835.

11. Shabani E, Dowlatshahi S, Abdekhodaie MJ (2020) Laboratory detection methods for the human coronaviruses. Eur J Clin Microbiol Infect Dis 28: 1-22. 
This work is licensed under Creative Commons Attribution 4.0 License

DOI: 10.19080/CTBEB.2021.20.556027

\section{Your next submission with Juniper Publishers will reach you the below assets}

- Quality Editorial service

- Swift Peer Review

- Reprints availability

- E-prints Service

- Manuscript Podcast for convenient understanding

- Global attainment for your research

- Manuscript accessibility in different formats ( Pdf, E-pub, Full Text, Audio)

- Unceasing customer service

Track the below URL for one-step submission https://juniperpublishers.com/online-submission.php 